\title{
Regional development without social conflicts on municipal territories. Subjects of public municipalities' control as institutions for forming public opinion and relieving social tension
}

\author{
Maria Plotnikova* \\ Administration of the city district of Krasnoturinsk, Molodezhnaya str., 1, 624440, Krasnoturinsk, \\ Russia
}

\begin{abstract}
Public councils and Public chambers, as subjects of public control at the federal, regional and municipal levels, are channels for forming public opinion of citizens about the government's activities by performing their institutional functions and tasks. Their effective activity contributes to the accumulation of public initiatives aimed at providing the region's development, improving the level and quality of people's life, ensuring their retransmission to the authorities for making the necessary decisions.

And if at the federal and regional levels their legal status is fixed by normative legal acts, at the municipal level there is no legal certainty to regulate the methods of creating and organizing the activities of local Public chambers.

The author conducted a study to identify efficiency criteria for the realization of the institutional functions of regional Public chambers and by necessity of efficiency criteria, formed on their basis for Public chambers and councils of the municipal level, which may differ, and by necessity of development of proposals for additional resources to increase their effectiveness.
\end{abstract}

\section{Introduction}

One of the goals of the strategic development of the region is to improve the quality of life of the population, and the work of the system as a whole should be directed on it, including the work on public control.

Functions of subjects of public control are regulated by legal acts of Russia, subjects, and municipalities. Subjects of public control include Public chambers of Russian regions, Public chambers and councils of municipalities [1].

Public councils and Public chambers are channels of forming public opinion of citizens about the activities of the government by performing its institutional functions and tasks.

\footnotetext{
* Corresponding author: mari19081977@yandex.ru
} 
As social institutions, they form the public opinion of the population on the territory of the Federation, subjects and municipalities.

Their effective activity contributes to the accumulation of public initiatives aimed at providing the region's development, improving the level and quality of people's life, ensuring their retransmission to the authorities for making the necessary decisions. Public chambers are discussion platforms for discussing the most urgent issues, at the same time they form public opinion of the population. Their task is also to prevent situations when certain destructive forces try to make people to protest and speculate on issues that people are particularly concerned about. They are necessary for the removal of social tension of social territorial communities and for the region's development.

The social significance of the Public chamber at different levels of the Russian Federation is assessed on the basis of goals it achieved, on organization and conducting of events, and on developed solutions. [2].

Subjects of public control acquire special significance on municipal territories, contribute to solving issues of local significance, and inform the authorities of a wellfounded position on solving socially significant decisions.

And if at the federal and regional levels its legal status is fixed by normative legal acts, at the municipal level there is no legal certainty to regulate the methods of creating and organizing the activities of local Public chambers.

Local chambers are created by decisions of the heads of municipalities, and decisions of municipal Councils, which cannot be considered successful from the point of view of the very nature of such bodies.

The newly enacted Law on public control in Russia also does not bring satisfaction. However, he strengthened the status of local public chambers, calling them subjects of public control at the municipal level.

The social significance of the Public chamber at different levels of the Russian Federation is assessed on the basis of goals it achieved, on organization and conducting of events, and on developed solutions.

Subjects of public control acquire special significance on municipal territories, contribute to solving issues of local significance, and inform the authorities of a wellfounded position on solving socially significant decisions.

And if at the federal and regional levels its legal status is fixed by normative legal acts, at the municipal level there is no legal certainty to regulate the methods of creating and organizing the activities of local Public chambers

Local chambers are created by decisions of the heads of municipalities, and decisions of municipal Councils, which cannot be considered successful from the point of view of the very nature of such bodies.

The newly adopted Law on public control in Russia also does not bring satisfaction. However, he strengthened the status of local public chambers, calling them subjects of public control at the municipal level. [3]

The problem is that the legal institution of the Public chamber does not guarantee its effectiveness, which determines the need to identify the real place of the Public chamber in the interaction of population and authorities, what is possible on the basis of application of sociological approach, which allows to measure the impact of Public chamber on public opinion of the population.

The uncertainty of the concept "social institution" in the annual reports, the absence of criteria of efficiency of public associations' activity, the imperfection of the mechanisms of interaction of civil society institutions and authorities, the uncertainty of the location of Public chambers and councils in government bodies; all this indicates that Public chambers and councils as bodies in the subjects and municipalities of the Russian Federation are relatively recent and are in the process of formation 
The study is held due to the analysis of legal and functional peculiarities of the subjects of public control in the interaction of social and territorial communities and authorities; the need to identify efficiency criteria of the institutional functions of regional Public chambers and formed on their basis efficiency criteria for the subjects of public control at the municipal level, the development of proposals for additional resources to enhance their effectiveness.

\section{Materials and methods}

The study was conducted between 2018 and 2020. The sources of information about the work of Public chambers and Public councils are annual reports on the activities of Federal and regional Public chambers for three years, annual reports posted on their official websites, the results of online surveys of the Public chamber of the Russian Federation conducted in 2019, and the opinions of regional officials published in the media. Scientific publications and monitoring of sites of municipalities of the Sverdlovsk region on the composition and activities of Public chambers and councils were analyzed on the topic of the effectiveness of public chambers. In 2018 a questionnaire survey was conducted in the territory of the middle city (Krasnoturyinsk Sverdlovsk region), on the efficiency of interaction of authorities with a population, in 2019 there conducted a questionnaire survey (evaluation of informing and receiving feedback, assessing knowledge of the official media, the local authorities population, interaction with expert, consultative and Advisory bodies - all this was researched), in 2020 expert interviews were taken from members of the Public chamber of the city of Krasnoturinsk and the Public Council of the village of Rudnichnoe.

\section{Results and discussion}

In the course of research in 2018, the majority of pensioners (48\%) answered the question of whether they know about the existence of a Public chamber in the Krasnoturinsk city district (figure 1), that yes, they know. The other groups of respondents answered in the negative.

Employees of industrial enterprises (52\%), employees of municipal unitary enterprises $(59 \%)$, entrepreneurs $(64 \%)$, and students (55\%) answered, "Do not know " State employees found it difficult to answer (47\%). 


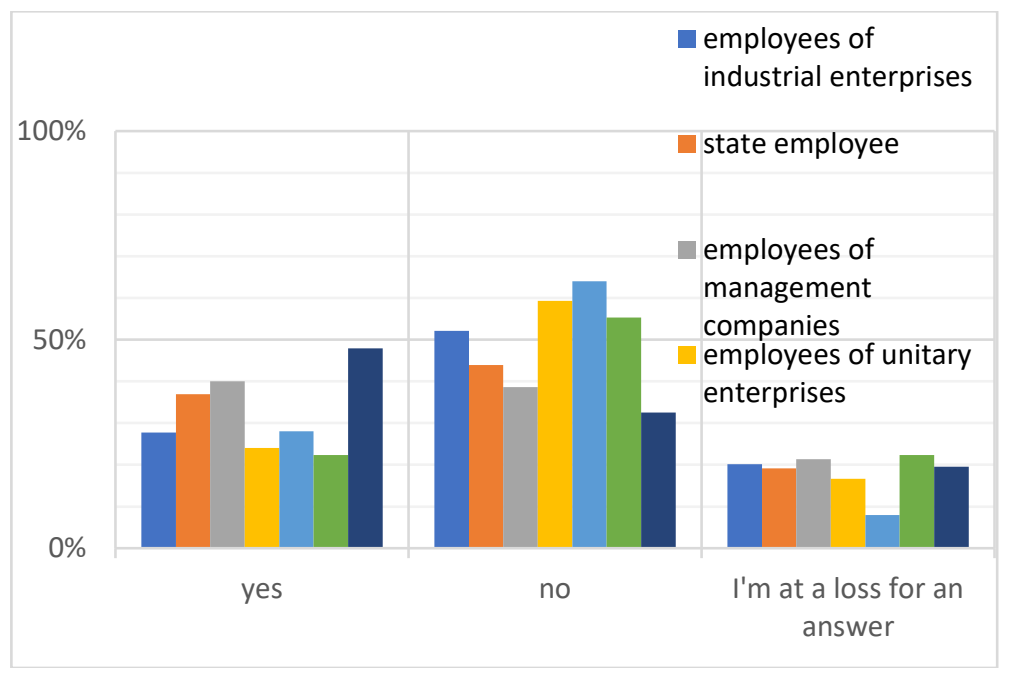

Fig. 1. Answers to the question: "Do you know about the existence of a Public chamber in the city?"

In response to the question whether respondents know that the dialogue between the population and the authorities can be carried out not only through communication via Internet resources or reception of citizens, but also through the Public chamber (figure 2), 355 respondents said that they do not know about this. Respondents from unitary enterprises, students and pensioners did not answer this question at all.

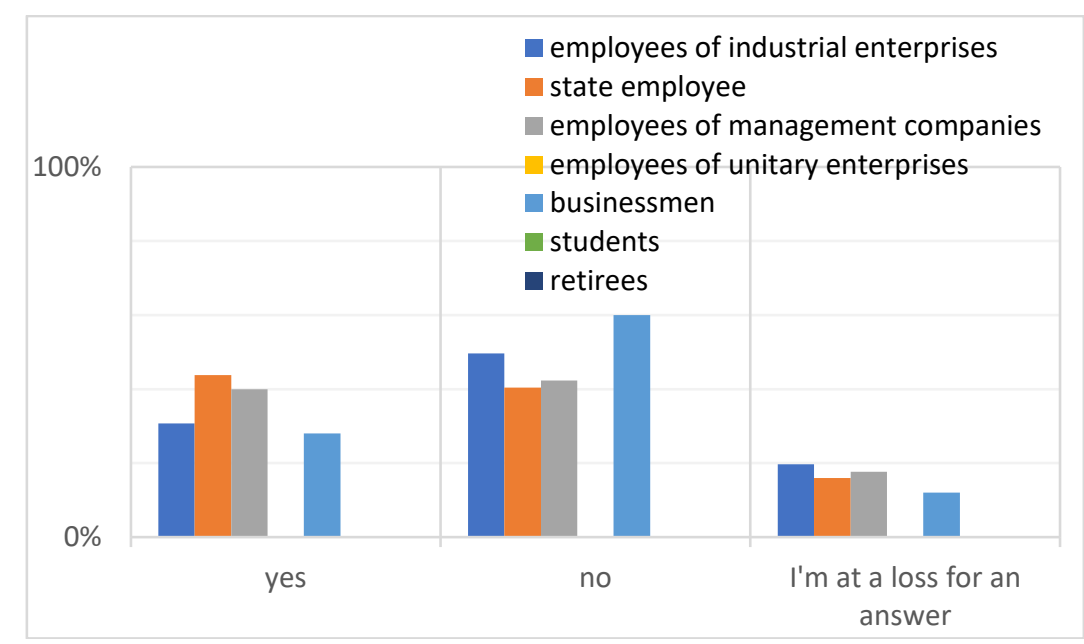

Fig. 2. Answers to the question: "Did you Know that the dialogue between the population and the authorities can also be carried out through the Public chamber?

When asked about the types of citizens ' participation in city life (figure 3 ), the majority of residents indicated public works and participation in the discussion of major issues $(53 \%)$.

Students (40\%), pensioners (55\%), employees of management companies $(25 \%)$, employees of unitary enterprises (40\%) mostly consider public works as a type of participation. Employees of industrial enterprises (29\%), state employees (24\%), and entrepreneurs $(35 \%)$ consider discussion of the most important issues as types of participation. 


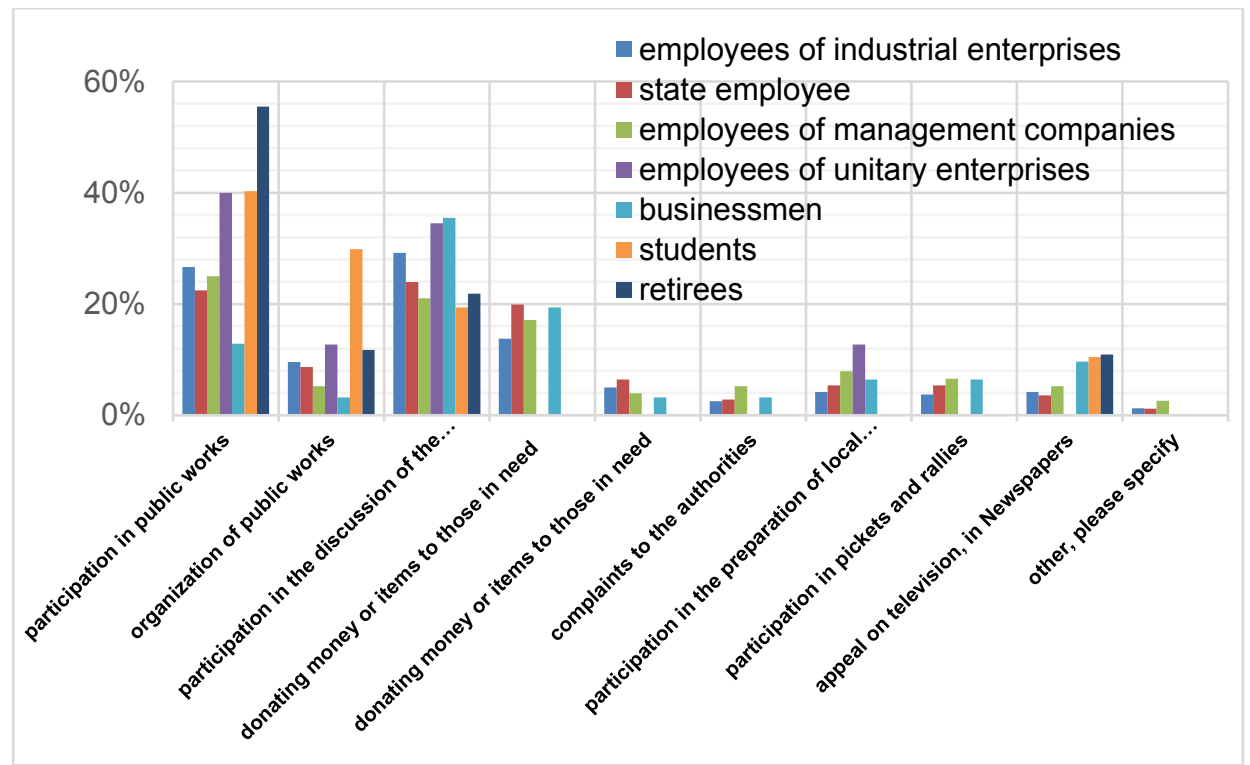

Fig. 3. Answers to the question: "Indicate acceptable types of participation in the local life of the city district"

Consequently, the municipal chamber does not fully perform its institutional functions, does not accumulate enough public initiatives aimed at ensuring the development of the territory, forming of public opinion of the population about the work of government bodies. There is also no information about public control. The population of the municipality, in its turn, is ready to participate in local life, as shown in figure 3. [4]

From the content analysis of the sites of neighboring municipalities (Severouralsky city district, Karpinsky city district), it can also be concluded that there is no public control, there are no results on the conduct of public control checks by public control subjects on their sites.

For comparison, in the neighboring municipality, Karpinsk city district, most of the members of its Public Chamber are heads of municipal institutions founded by local governments, which subsequently will cause difficulties in carrying out functions of public control, and therefore will affect the forming of public opinion about the work of the authorities.

Criteria and efficiency indicators are needed to evaluate the activities of such public bodies. Today, there are no such methods. The literature is guided by descriptive characteristics and subjective judgments about the work of such public bodies [5].

The study of the interaction of such social institutions of civil society with the authorities is just beginning. And the development of their efficiency criteria is relevant in this study.

The Federal legislation on Public chambers in the constituent entities of the Russian Federation establishes common goals and objectives for all regional public chambers.

The provisions of municipal public chambers are extrapolated with the regional ones, there is no unified position on the procedure for creating and functioning of them at the Federal level.

In this case, social effectiveness is not always can be measured quantitatively and statistically, and qualitative methods are required to assess it. [6]Here we applied sociological research, in which the object is the social efficiency of the Public chamber [7]. 
In their cases on evaluating the effectiveness of public chambers of the Vladimir and Saratov regions, scientists Bryantsev, I. I., Evstifeev R. V. came to the conclusion that the Ongoing studies determine the degree of population's satisfaction with the municipal management and work of the Public chamber, and hence indicate the presence of a link mechanism between the public authorities and population through the staff and content of the activities of the Public chamber [8].

The Efficiency as a governance formed by vertical authority is represented by normative legal documents that reflect the assessment of efficiency: presidential Decrees, Government resolutions, regulatory legal acts of subjects. In terms of structuring, the goals are set by the top management level, and the effectiveness of actions is shown in the form of feedback as a response of society to management decisions. Hence, as a criterion of effectiveness, we can consider a legally institutionalized form of public control.

The institutional functions of the Public chamber for carrying out the expertise of legal acts, carrying out the public examination of normative legal acts, sending recommendations to the authorities in the direction of priorities for supporting public organizations, draw another significant criterion for its effectiveness, such as coordinating social projects in the territory representing the interests.

The institutional functions of the regional chamber are established by the Federal law No. 183-FZ of 23.06.2016, which establishes common goals and objectives for all chambers for interaction between citizens, non-profit organizations, and authorities in order to take into account the needs and interests of citizens and non-profit organizations when forming policies for public control over the authorities' activities in the relevant territory of the region [9].

Priority functions of the public chamber of the region (subject) are: organization of interaction between citizens and authorities, public supervision.

From the provisions of Federal law No. 183-FZ and the above-mentioned definitions of efficiency, it is possible to form efficiency criteria, such as:

1. The composition and procedure of formation of Public chamber as platform for negotiations, contributing to the representation of social and territorial communities, thereby contributing to ease social tension in the region's territory.

2. Exercising of public control over the work of government bodies and coordinating the implementation of social projects by non-profit organizations in the territory representing their interests.

Based on the above, the process of institutionalization, as well as the formation of public opinion in the territory by such a representative body as the public chamber, is directly dependent on the efficiency of its work. Composition and activities Public chamber can be considered through the main performance criteria, such as: the formation of the chamber of representatives of civil society and the content of its activities through public control and coordination of social projects in the territory representing the interests.

However, the formed hypothesis of the regional level on the criteria of effective work of subjects of public control for the application of such criteria at the municipal level requires additional research.

According to the established regulations, municipal chambers are mainly formed by the head, the Duma, and the remaining part is filled on the recommendations of already recruited members. Without conducting selection procedures, as an open equal access for leaders of initiative groups of citizens, public organizations and other civil society institutions.

Representatives of subjects of public control of the municipality face a number of difficulties in fulfilling such criteria as public control. First, public control requires a number of competencies, which is very difficult at the municipal level. Second, it takes a 
considerable amount of time to acquire competencies and conduct public control procedures, mainly at time, free from the main work.

Since representatives of subjects of public control at the municipal level carry out their activities on a voluntary basis, most of them do not have the necessary competencies, they have to perform such work in their free time. The legislation does not provide social guarantees to members of municipal chambers on the inclusion of their time of public work to working hours and payment fort (as in the Public chamber of the Russian Federation) . While public control checks require certain competencies and conduct them during working hours for everyone.

\section{Conclusions}

Taking into account the above, for subjects of public control as channels for forming public opinion about the work of government bodies at the municipal level, the efficiency criteria for the realization of their institutional functions will differ from the efficiency criteria of subjects of public control of the Russian Federation's subjects

The social effectiveness of the activities of subjects of public control at the local level is in their systematic performance of all established institutional functions. The main significant criteria for the effectiveness of their activities, contributing to the removal of social tension in the municipalities and the development of the region, are:

1. The composition of the chamber (Council), as the procedure for its (its) formation, taking into account the peculiarities of the territorial approach and traditions of a certain territory of the municipality.

2. The Second is the competence of the members of the Public chamber (Council) to perform the institutional functions of the Public chamber (Council) directly for conducting public control and coordination of social projects of the territory and other institutional functions of such a social institution.

Local self-government bodies need to work closely with subjects of public control and understand the needs of their competencies. They can be recommended foreffective interaction with subjects of public control joint competence training on state platforms, as well as on the sites of serious socially responsible organizations, such as the EVRAZ and RUSAL groups of Companies.

Also, on this research topic, you can answer questions about the possibility of granting additional institutional functions to public chambers and municipal councils on issues that are not included in local government issues.

In connection with appeals to subjects of public control of citizens with issues that are not within the competence of local self-government bodies, public chambers (councils) could solve them with territorial state authorities, enterprises and institutions of various forms of ownership, while reducing social tension in the territory and thereby contributing to the development of the region.

\section{References}

1. On the basis of public control in the Russian Federation: Federal law dated 21.07.2014 No. 212-FZ (as amended on December 27, 2018), http://www.consultant.ru/

2. D. Zakharian, Actual issues of sociological science: theory, methodology, practice, 52 (2013)

3. T.N. Mikheeva, D.S. Mikheev, Proceedings of the 32nd International Business Information Management Association Conference, IBIMA 2018 - Vision 2020: Sustainable Economic Development and Application of Innovation Management from 
Regional expansion to Global Growth. On problems of definition of public control subjects., 7680 (2018)

4. M. A. Plotnikova, Management issues, 6, 61 (2019)

5. D. A. Zakharyan, Zh. V. Puzanova, Bulletin of the peoples ' friendship University of Russia., 2, 52 (2014)

6. Yu. P. Ozornina, Scientific Bulletin of the Ural Academy of public administration, №. 4, 20 (2011)

7. I. I. Bryantsev, R. V. Evstifeev, Issues of state and municipal administration. Problems of evaluating the effectiveness of state and public institutions (on the example of public chambers of the Vladimir and Saratov regions., 1, 115 (2020)

8. M. V. Dzakhoeva, Matters of Russian and International Law., 127 (2019)

9. On the Public Chamber in the Russian Federation: Federal Law dated 04.04.2015 No. 32-OZ (as amended on December 05, 2017), http://www.consultant.ru/ 